\title{
Water consumption of field crop species' protein formation
}

\author{
Márton JOLÁNKAI ${ }^{1}$ - Ákos TARNAWA ${ }^{1}$ - Zsuzsanna SÓFALVY² - \\ Zsolt SZENTPÉTERY ${ }^{3}-$ Katalin M. KASSAI $^{1}$ \\ 1: Szent István University Crop Production Institute 2100 Gödöllő Páter Károly utca 1. Hungary. \\ E-mail: kassai.katalin@mkk.szie.hu \\ 2: Railway Health Care Ltd. Budapest, Hungary. sofalvy@gmail.com \\ 3: Szent István UniversityFaculty of Mechanical Engineering E-mail: szentpetery.zsolt@gek.szie.hu
}

Keywords: Water footprint, protein formation, field crop yield, evapotranspiration

\section{Introduction}

Water supply is one of the major physiological factors influencing plant growth and development. The water footprint shows the extent of water use in relation to consumption. Crop water use, consumptive use, and evapotranspiration are terms used interchangeably to describe the water consumed by a crop. This water is mainly used for physiological processes, only a negligible amount is retained by the crop for building its tissues. Water requirements for crops depend mainly on species and environmental conditions.

\section{Materials and methods}

An assessment study has been done at the Szent István University, Gödöllö to evaluate and identify the water footprint of protein yield of field crop species. Six field crop species (Sugar beet Beta vulgaris, winter barley Hordeum vulgare, winter wheat Triticum aestivum, maize Zea mays, potato Solanum tuberosum, and alfalfa Medicago sativa) were involved in the study. Evapotranspiration patterns of the crops studied have been identified and physiologically reliable protein ranges within crop yields were evaluated.

\section{Results and discussion}

Table 1 Water footprint of six field crop species (SZIU, 2017)

\begin{tabular}{|l|c|c|c|c|c|}
\hline Crop & protein \% & crop yield tha ${ }^{-1}$ & $\begin{array}{c}\text { protein yield } \\
\mathrm{kgha}^{-1}\end{array}$ & $\begin{array}{c}\text { protein } \mathrm{kg} / \mathrm{ET} \\
\mathrm{mm}\end{array}$ & $\begin{array}{c}\text { litre / } \\
\text { protein } \mathrm{g}\end{array}$ \\
\hline Medicago sativa & 18.0 & $4.35^{*}$ & 783 & 1.32 & 44.9 \\
\hline Solanum tuberosum & 2.0 & 24.9 & 498 & 0.97 & 52.7 \\
\hline Beta vulgaris & 1.1 & 41.2 & 453 & 0.96 & 49.1 \\
\hline Triticum aestivum & 13.0 & 4.8 & 624 & 1.83 & 23.1 \\
\hline Hordeum vulgare & 16.5 & 4.1 & 676.5 & 1.88 & 18.9 \\
\hline Zea mays & 9.5 & 5.8 & 551 & 1.09 & 46.5 \\
\hline *hay & & & &
\end{tabular}

Water footprint of six field crop species (Sugar beet Beta vulgaris, winter barley Hordeum vulgare, winter wheat Triticum aestivum, maize Zea mays, potato Solanum tuberosum, and alfalfa Medicago sativa) were evaluated.

The results obtained presented in Table 1 suggest, that water footprint of cereals proved to be the lowest, however maize values were highly affected by the high variability of protein yield. Alfalfa, potato and sugar beet water footprints were in accordance with their evapotranspiration patterns. 


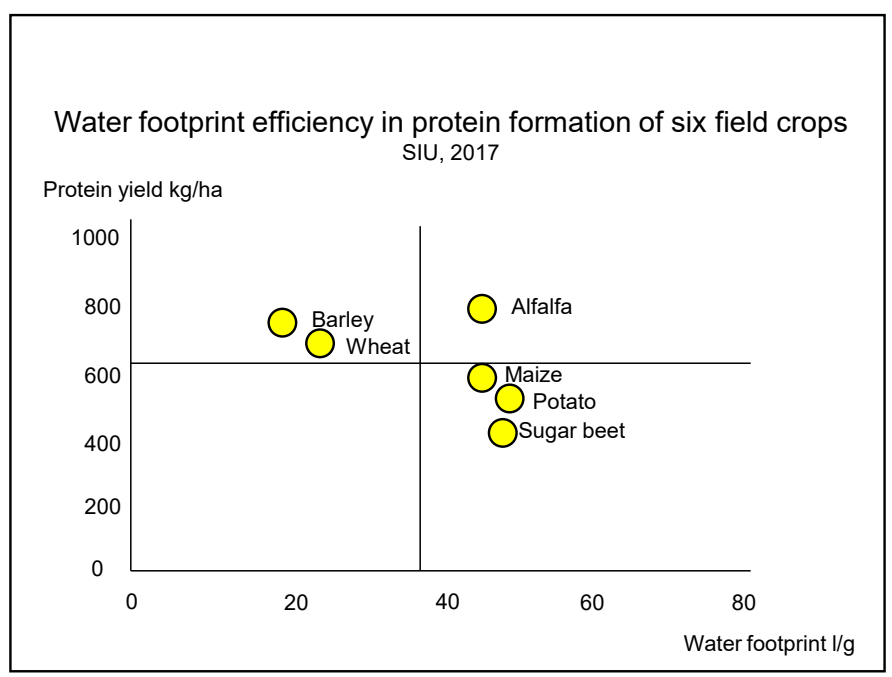

Figure 1. Water footprint efficiency (SZIU 2017)

Figure 1. provides information on the magnitude of protein yields of certain field crop species and the amount of water used for its formation.

\section{Conclusions}

Physiological characteristics of field crop species highly influenced the magnitude of their water footprint. According to the results of the study protein yield proved to be the most reliable basis for comparison of water footprint performance

\section{Acknowledgement}

This article presents research results gained from a long term trial supported by TÁMOP, NVKP and VKSZ funds of the Government of Hungary.

\section{References}

Jolánkai M., Kassai M.K., Tarnawa Á. (2018): Water footprint of field crop species based on their protein yield. In: Transport of water, chemicals and energy in the soil-plant-atmosphere system. Ed.: A. Celková. UH-SAV, Bratislava. 32-36 pp. ISBN 978-50-89139-40-8.

Várallyay, G. (2008): Extreme soil moisture regime as limiting factor of the plants' water uptake. Cereal Research Communications . Suppl. 3-6 pp. https://www.jstor.org/stable/90002626

Wichelns, D. (2010): Virtual water and water footprints offer limited insight regarding important policy questions. International Journal of Water Resources Development. 26. 4. 639-651pp. https://iahr.tandfonline.com/doi/ abs/10.1080/07900627.2010.519494 https://doi.org/10.1080/07900627.2010.519494 